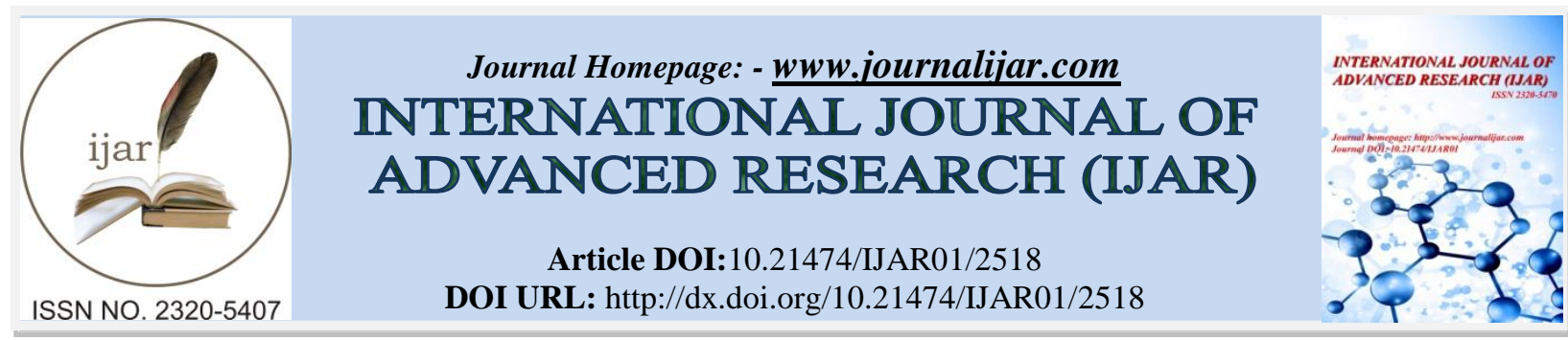

RESEARCH ARTICLE

\title{
THE EFFECT OF VALUE ENGINEERING METHOD INSUPPORTING COMPETITIVE ADVANTAGE (FIELD STUDY IN THE PAINTS COMPANIES - KHARTOUM STATE)
}

Dr. Abubkr Ahmed Elhadi Abdel Raheem.

Assistant Professor - Department of Accounting - Faculty of Managerial and Financial Sciences - Peace University, Sudan.

\section{Manuscript Info}

.........................

Manuscript History

Received: $x x x x x x x x x x x x x x x$

Final Accepted: $x x x x x x x x x x x$

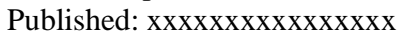

Key words:-

Value Engineering - competitive advantage.

\section{Abstract}

This study aimed to identify the effect of value engineering in Activating Competitive Advantage (Field Study in the Paints Companies - Khartoum State). The study tested one hypothesis which are: There are significant relationship between applied the value engineering method and support the competitive advantage of paints companies -Khartoum state. Researcher distributed (100) questionnaire forms among some of the workers in the field selected randomly (89) Forms were collected as $89 \%$. Statistical package of social sciences programmer (SPSS) used for analyzing data. The study reached some findings from which Value Engineering contributes in reducing costs during the products design stage, Value Engineering contribute to supporting the competitive advantage, Some of the study recommended to: there is necessity in applying the strategic cost methods together to activate the competitive advantage continuously, to do more studies in all the Sudanese industrial companies to the benefit of adopting the strategic methods in decreasing costs and to support the competitive advantage.

Copy Right, IJAR, 2016,. All rights reserved.

\section{Introduction: -}

\section{The Problem: -}

The heightened competition and the challenges facing manufacturing companies today have become many, so you should pay attention to the role of information in terms of administration, which Alone industrial companies to the acceleration in the development of management information systems based on computer information and keep abreast of the rapid developments in the field of strategic methods used to reduce costs systems while maintaining the quality of the products so that these companies are able to achieve the customer's wishes and support competitive advantage - Khartoum State.

Suffers companies at the present time of constant development in the fields of technology and the evolution of the methods used to reduce costs and maximize profitability and increase quality, thus companies must keep abreast of all the developments in the modern business environment so that it can satisfy the desires of customers and support competitive advantage, through the above is the problem of study the following questions: -

Is there an effect to applied the value engineering method on support the competitive advantage in paints companies - Khartoum State? 


\section{The Objectives: -}

Study aimedto identify to concept the value engineering method and knowledge the effect to supporting the competitive advantage inpaints companies - Khartoum State.

\section{The Importance: -}

The importance of scientific study in the value engineering methods recently used and there are few studies that have addressed the issue of value engineering in order to reduce costs, thus considered this subject in addition to libraries for use graduate students in the field of cost, is the practical significance of the study in the need to capitalize on the paints companies - Khartoum State of the possibilities available and new technologies used to reduce costs, including value engineering, leading to support the competitive advantages of the products of these companies.

\section{Hypothesis; -}

To achieve the objectives of the study were tested this hypothesis:

There aresignificant relationship between applied the value engineering method and support the competitive advantage of paints companies -Khartoum state.

\section{Previous Studies\&Theoretical Framework: - Annappa Study (2012): -}

This paper presents the basic fundamental of value engineering that can be implemented in any product to optimize its value. A case study of a Universal Testing Machine (UTM) is discussed in which the material, design of components is changed according to the value engineering methodology. In the present case study, it is observed that the unnecessary increase in cost is due to the use of expensive material, increase in variety of hardware items and thereby increasing the inventory and so on. Therefore, we have selected some components from UTM i.e. Hand Wheel, Range Selector Knob, Top Bearing Bracket Assembly, Dial Bracket, Recorder Gearetc. and we have applied value engineering technique for the cost reduction of these components of UTM. Therefore, by Value Engineering technique, Design modification for Dial Bracket and Top Bearing Bracket Assembly, use of alternative less expensive material for Recorder Gears, Range Selector Knob and Hand Wheel is suggested in this case study and thereby which cost reduction is achieved.

\section{Dehmourdi Study (2014):-}

The purpose of this paper is to understanding of the definition of value engineering and identification of reason of unnecessary cost in construction industry, and also for development and applying and implementation of value engineering in construction. The purpose of the paper defines is also in minimizing the cost, development of projects, quality and function, optimization of resources, Significant Cost Savings avoidance, Transfer, this research study used a combination of different research methodologies including the standard research methodology and as well the ingenuity of the author for innovation of a new method to approach the answers of the research questions and obtaining the results and the particular outcomes of the study, of the most important results of the study the values engineering is very useful for coordination with design architecture- engineer and construction manager for coordination, scheduling and also effort to Recommendation the design Architecture Engineer of information requirements and making decision in so many items for success in the project and better understanding of the jobs.

\section{Bharathi Study (2014):-}

Saving money and, at the same time, providing better value is a concept that everyone can support. The benefits of spreading our invested rupee, building more for less money, increasing efficiency and cutting down our dependency on energy-intensive buildings and plant facilities need to be recognized today and pursued in the future. Value Engineering is not just "good engineering", it is not a suggestion program or a routine plan review, but it is a new, fresh look at problems starting from basic functional requirements - an independent approach to the project.

Value Engineering is a methodology used to analyze the function of the goods and services and to obtain the required functions of the goods and service of the user at the lowest total cost without reducing the necessary quality of performance. The program seeks to improve the management capability of people and to promote progressive change by identifying and removing unnecessary cost. 


\section{The Concept of Value Engineering: -}

Value Engineering is the systematic application of recognized techniques which identify the function of the product or service, establish a monitory value for that function and provide the necessary function reliability at the lowest overall cost. The purpose of the Value Engineering Systematic Approach is to provide each individual with a means of skillfully, deliberately and systematically analyzing and controlling the total cost of product. This total cost control is accomplished, in the main, by the systematic analysis and development of alternative means of achieving the functions that are desired and required. The purpose of VESA is well served when the user is able to define and segregate the necessary from the unnecessary and thereby develop alternate means of accomplishing the necessary at a lower cost. Hence Value Engineering may be defined as, "an organized Procedure for efficient identification of unnecessary cost (Annappa,2012), Value Engineering is a systematic process using a team from a variety of disciplines to Improve the value of a project through the analysis of its functions. The functional values of Transportation projects are usually determined through initial planning and scoping process leaving the improved value of a project to be realized through the value engineering process. The value engineering process incorporates, to the Extent possible, the values of design, construction, maintenance, contractors, state, local and federal Approval agencies, other stakeholders, and the public (Dehmourdi,2014),Effective Value Engineering results from the coordinated efforts of a team of qualified members, each member by virtue of specialist knowledge and experience being empowered to make decisive statements commitments within the team appropriate to the department he represents. Thus the path to product profitability would bear the approval stamp of Research, Design, Manufacturing and Marketing, with Costs being a co-opted contribution as occasion demanded (Ferguson,1968),During the period 1957 to 1963, the new technique of Value Engineering was having a noticeable impact in the U.S.A., and investigations made by the personnel of Design Cost Control provided the necessary evidence to convince them that the Value Engineering functional approach to cost reduction was very similar to theirs. In fact, from the subsequent trials which were carried out it became obvious that this approach enabled many hidden unnecessary costs to be revealed which would otherwise remain undetected(Crum,1986), Value Engineering is now defined as a systematic application of recognized techniques by multi-disciplined team(s) which identifies the functions of a product, process, service or system; establishes a worth for the functions; generates alternatives through the use of creative thinking and provides the needed functions, reliably, at the lowest overall cost (Mukhopadhyaya,2009), Value Engineering means an analysis of the functions of a program, project, system, product, item of equipment, building, facility, service, or supply of an executive agency performed by qualified agency or contractor personnel, directed at improving performance, reliability, quality, safety, and life cycle costs(Younker,2003).

\section{Concept of Competitive Advantage: -}

Competitive advantage is an organization's ability to perform in one or more ways that competitorswill not and cannot match (Kotler, 2000), Competitive advantage for the organization's ability to provide the products its customers that is they know the more valuable of the competitors provide Similar cases(Saloner,2001), Competitiveness of a firm is its capacity to achieve its targets. These targets are likely to be expressed in a variety of terms depending on the context(Barney 2002).

Competitive advantage is the optimal utilization of resources to add value to the product form that cannot be achieved from the rest of the competitors (Omirh,2006).

Competitive advantage as the process of checking and analyzing factors to the functions and activities of production and marketing and finance departments and human resources in order to identify the strengths and internal weaknesses so you can work with the maximum efficiency to exploit the opportunities and face the threats in the external environment, it's also dealing with a range of skills and techniques, resources and capabilities that management can coordinate and invest (Mohammed,2009).

\section{Analytical Framework: -}

The study sample include staff paints companies - Khartoum state, and there are 5 companies for the manufacture of paints, Researcher distributed (100) questionnaire forms among some of the workers in the field selected randomly (89) Forms were collected as $89 \%$. Statistical package of social sciences programmer (SPSS) used for analyzing data, the researcher used statistical methods following: frequencies, percentages, median, chi square to test the hypothesis of study. 
Table 1:- Frequency distribution the sample on the hypothesis phrases

\begin{tabular}{|c|c|c|c|c|c|c|}
\hline Phrase & $\begin{array}{l}\text { Strongly } \\
\text { Agree }\end{array}$ & Agree & $\begin{array}{l}\text { neutra } \\
\text { l }\end{array}$ & disagree & $\begin{array}{l}\text { Strongly } \\
\text { disagree }\end{array}$ & Total \\
\hline $\begin{array}{l}\text { Paints companies have good Accounting } \\
\text { system to applied the value engineering. }\end{array}$ & 40 & $\begin{array}{l}27 \\
30.3 \% \\
\end{array}$ & $\begin{array}{l}5 \\
5.6 \% \\
\end{array}$ & $\begin{array}{l}17 \\
19.1 \% \\
\end{array}$ & $\begin{array}{l}0 \\
0\end{array}$ & $\begin{array}{l}89 \\
100 \% \\
\end{array}$ \\
\hline $\begin{array}{l}\text { Paints companies have qualified human } \\
\text { resources to applied value engineering. }\end{array}$ & $\begin{array}{l}5 \\
5.6 \%\end{array}$ & $\begin{array}{l}68 \\
76.4 \%\end{array}$ & $4.5 \%$ & $\begin{array}{ll}12 \\
13.5 \%\end{array}$ & $\begin{array}{l}0 \\
0\end{array}$ & $\begin{array}{l}89 \\
100 \%\end{array}$ \\
\hline $\begin{array}{l}\text { Strategic cost contribute to reduce the costs of } \\
\text { product design stage through value } \\
\text { engineering. }\end{array}$ & $\begin{array}{l}11 \\
12.4 \%\end{array}$ & $\begin{array}{l}55 \\
61.8 \%\end{array}$ & $\begin{array}{l}13 \\
14.6 \%\end{array}$ & $\begin{array}{l}4 \\
4.5 \%\end{array}$ & $\begin{array}{l}6 \\
4.5 \%\end{array}$ & $\begin{array}{l}89 \\
100 \%\end{array}$ \\
\hline $\begin{array}{l}\text { Value Engineering contribute to reduce } \\
\text { production costs by re-engineering the product. }\end{array}$ & $\begin{array}{l}34 \\
38.2 \%\end{array}$ & $\begin{array}{l}26 \\
29.2 \%\end{array}$ & $\begin{array}{l}16 \\
18 \%\end{array}$ & $\begin{array}{l}1 \\
1.1 \%\end{array}$ & $\begin{array}{l}12 \\
13.5 \%\end{array}$ & $\begin{array}{l}89 \\
100 \%\end{array}$ \\
\hline $\begin{array}{l}\text { Value Engineering contribute to the optimal } \\
\text { utilization of the production resources . }\end{array}$ & $\begin{array}{l}48 \\
53.9 \%\end{array}$ & $\begin{array}{l}26 \\
29.2 \%\end{array}$ & $\begin{array}{l}0 \\
0\end{array}$ & $\begin{array}{l}15 \\
16.9 \%\end{array}$ & $\begin{array}{l}0 \\
0\end{array}$ & $\begin{array}{l}89 \\
100 \%\end{array}$ \\
\hline $\begin{array}{l}\text { Value Engineering contribute to achieving the } \\
\text { aspirations of customers and increase the } \\
\text { competitiveness of paints companies }\end{array}$ & $\begin{array}{l}19 \\
21.3 \%\end{array}$ & $\begin{array}{l}56 \\
62.9 \%\end{array}$ & $\begin{array}{l}5 \\
5.6 \%\end{array}$ & $\begin{array}{l}0 \\
0\end{array}$ & $\begin{array}{l}9 \\
10.1 \%\end{array}$ & $\begin{array}{l}89 \\
100 \%\end{array}$ \\
\hline
\end{tabular}

\section{Spss data 2016.}

through Table 1 the researcher observes that all of the sample agree with the hypothesis phrases.

Hypothesis Study Test: -

Table 2: -Median \& Chi-Square.

\begin{tabular}{|l|l|l|l|}
\hline Phrase & Median & $\begin{array}{l}\text { Chi- } \\
\text { Square }\end{array}$ & $\begin{array}{l}\text { Asymp. } \\
\text { Sig }\end{array}$ \\
\hline $\begin{array}{l}\text { Paints companies have good Accounting system to applied the value } \\
\text { engineering. }\end{array}$ & 4 & 29.787 & .000 \\
\hline Paints companies have qualified human resources to applied value engineering. & 4 & 127.135 & .000 \\
\hline $\begin{array}{l}\text { Strategic cost contributes to reduce the costs of product design stage through } \\
\text { value engineering. }\end{array}$ & 4 & 100.157 & .000 \\
\hline $\begin{array}{l}\text { Value Engineering contribute to reduce production costs by re-engineering the } \\
\text { product. }\end{array}$ & 4 & 36.449 & .000 \\
\hline $\begin{array}{l}\text { Value Engineering contribute to the optimal utilization of the production } \\
\text { resources. }\end{array}$ & 5 & 19.034 & .000 \\
\hline $\begin{array}{l}\text { Value Engineering contribute to achieving the aspirations of customers and } \\
\text { increase the competitiveness of paints companies }\end{array}$ & 4 & 72.933 & .000 \\
\hline
\end{tabular}

\section{Spss data 2016.}

Through the median researcher observes that all of the sample agree with the hypothesis phrases, and a level of significance Chi square (.000) less than the significance level 0.05 This underlines significant relationship between applied the value engineering method and support the competitive advantage of paints companies -Khartoum state.

\section{Result: -}

1. Value Engineering contribute to achieving the customer desires.

2. Value Engineering contributes in reducing costs during the products design stage.

3. Value Engineering contribute to supporting the competitive advantage.

\section{Recommended: -}

1. There is necessity in applying the strategic cost methods together to activate the competitive advantage continuously.

2. To do more studies in all the Sudanese industrial companies to the benefit of adopting the strategic cost in decreasing costs and to support the competitive advantage. 


\section{References: -}

1. Kotler, P., (2000). Marketing Management Analysis, Planning and Control. 5th Edn. Prentice-Hall, Englewood Cliffs, New Jersey.

2. Saloner, Garth, Andrea Shepard and Joel Podolny (2001), "Strategic Management", John Wiley \& Sons, New York.

3. Barney, (2002), Gaining and Sustaining Competitive Advantage, 2nd Ed. Prentice Hall, New Jersey,

4. Omirh Mohammed, the application of the overall generosity and ISO specifications and their impact in achieving competitive advantage, Journal of Administrative Sciences, College of Administrative Sciences, Islamic University of Omdurman, Sudan, First Issue, 2006.

5. Mohammed, Kamal Abu Amsha, (2009), the dimensions of the competitive advantage of the Arab companies, Dubai, Research Center Publications.

6. Mukhopadhyaya, Anil Kumar, (2009), Value Engineering Mastermind, SAGE Publications India Pvt Ltd, New Delhi.

7. Younker, Del L, (2003), Value Engineering (Analysis and Methodology), Marcel Dekker, New York.

8. Dehmourdi, Seyed Ali Mousavi, (2014), Value Engineering and Reason of Unnecessary Cost in Construction Industry,Australian Journal of Basic and Applied Sciences, 8(13), pp 583-588.

9. Dehmourdi, Seyed Ali Mousavi, (2014), Value Engineering and Reason of Unnecessary Cost in Construction Industry,International Journal of Scientific Engineering and Technology Research Volume.03, IssueNo.12, pp 2699-2702.

10. Bharathi,V and Paranthaman, R, (2014), Application of Value Engineering in Construction Building, Indian Journalof Applied Research, Volume 4, Issue 4,pp 138-138.

11. Annappa,ChouguleMahadeo and ShrikantPanditrao, Kallurkar, (2012),Applicationof Value Engineeringfor Cost Reduction - A Case Studyof Universal Testing Machine, International Journal of Advances in Engineering \& Technology, Vol. 4, Issue 1, pp. 618-629.

12. Crum. W, (1986) Value Engineering in Rolls-Royce Aero Engine Design, journal of Value Engineering Vo 1 No 1 , pp 23 -26.

13. Ferguson.Rex, (1986), Value Engineering, its Contribution to Profitability, journal of Value Engineering Vo 1 No 1, pp 11-14. 